\title{
Identifikasi pH Larutan Antosianin Kol Merah (Brassica Oleracea Var.) terhadap Kinerja Prototipe Dye Sensitized Solar Cell (DSSC)
}

\author{
Ferri Rusady Saputra, ${ }^{*}$ Suryasatriya Trihandaru, dan Adita Sutresno ${ }^{\dagger}$ \\ Progam Studi Pendidikan Fisika, dan Progam Studi Fisika, Fakultas Sains dan Matematika \\ Universitas Kristen Satya Wacana, Jl. Diponegoro No. 52-60, Salatiga 50711
}

\begin{abstract}
Intisari
Kol merah adalah salah satu bahan organik yang mengandung antosiani. Antosianin ini dapat dimanfaatkan sebagai dye dalam pembuatan prototipe Dye Sensitized Solar Cell (DSSC) sebagai donor elektron. Pada artikel ini dilaporkan bahwa sel surya direndam dalam larutan ekstrak kol merah (Brassica Oleracea Var.) dengan variasi $\mathrm{pH}$ larutan yang berbeda-beda yaitu pada $\mathrm{pH} 1,5 ; 2,5$; dan 3,5. Hasil pengukuran menunjukkan bahwa sel surya dengan perendaman larutan antosianin kol merah pH 3,5 memiliki hasil keluaran paling baik yaitu pada rangkaian terbuka diperoleh arus pendek $\left(\mathrm{I}_{s c}\right)$ sebesar $56 \mu \mathrm{A}$, pada tegangan terbuka $\left(\mathrm{V}_{o c}\right)$ diperoleh sebesar $250 \mathrm{mV}$ dan besar rapat arus sebesar $24,89 \mu \mathrm{A} / \mathrm{cm}^{2}$ pada luasan $15 \mathrm{~mm} \times 15 \mathrm{~mm}$. Nilai efisiensi konversi sel surya mencapai $2,55 \times 10^{-3} \%$.
\end{abstract}

\begin{abstract}
Red cabbage is one of the organic materials containing anthocyanin. Anthocyanin can be used as the dye in Dye sensitized Solar Cell (DSSC) prototype manufacture as the electron donor. In this study, the solar cell was immersed in the extract solution of red cabbage (Brassica oleracea Var) with $\mathrm{pH}$ varying at $\mathrm{pH} 1.5, \mathrm{pH} 2.5$, and $\mathrm{pH}$ 3.5. The measurement results showed that the solar cell with red cabbage anthocyanin soaking solution at $\mathrm{pH}$ of 3.5 and the best result as at the open circuit is obtained $56 \mu \mathrm{A}$ of short circuit $\left(\mathrm{I}_{s c}\right)$, at the open voltage $\left(\mathrm{V}_{o c}\right)$ is obtained $250 \mathrm{mV}$ and $24.89 \mu \mathrm{A} / \mathrm{cm}^{2}$ of current density in the $15 \mathrm{~mm} \times 15 \mathrm{~mm}$ area. The conversion efficiency value of solar cell reached $2.55 \times 10^{-3} \%$
\end{abstract}

KATA KUNCI: pH, anthocyanin, Dye Sensitized Solar Cell (DSSC)

\section{PENDAHULUAN}

\section{Krisis Energi}

Bio sel surya Dye Sensitized Solar Cell (DSSC) merupakan sumber energi alternatif sebagai pengkonversi energi matahari menjadi energi listrik dengan memanfaatkan zat alam sebagai fotosensitizer. Mengingat matahari merupakan sumber energi yang sangat besar, terkait dengan letak Indonesia yang berada pada garis katulistiwa, dalam sehari wilayah indonesia disinari matahari selama 10-12 jam, total intensitas penyinaran rata-rata $4,5 \mathrm{kWh}$ permeter persegi perhari. Lama ratarata matahari bersinar berkisar 2000 jam per tahun sehingga tergolong kaya sumber energi matahari [1]. Berkaitan dengan pemanfaatkan sumber energi matahari, Michael Grätzel adalah peneliti yang pertama kali berhasil mengembangkan sistem sel surya tersintesa pewarna $[2,3]$. Penelitianya me-

\footnotetext{
*E-MAIL: ferrirusady marsa@ymail.com

${ }^{\dagger}$ E-MAIL: aditaestaff.uksw.edu
}

nunjukan bahwa kelebihan dari bio sel surya harganya murah dan tidak menggunakan peralatan canggih sehingga mudah dibuat [3-5]. Bio sel DSSC ini perlu dikembangkan mengingat kebutuhan akan energi listrik pada waktu lama akan semakin meningkat yang dikarenakan oleh pemakaian listrik yang tidak terkontrol, akibat pertumbuhan ekonomi dan penduduk yang pesat. Ini akan menimbulkan permasalahan yaitu krisis energi listrik. Target pertumbuhan ekonomi selama 5 tahun kedepan telah dipatok pada angka 7\% yang berarti harus ada persiapan penyediaan listrik dengan laju pertumbuhan sekitar 10,5\% per tahun. Jika mengacu dari pertumbuhan tersebut maka tahun 2020 perlu penambahaan 30.000 $\mathrm{mW}$ untuk wilayah Jawa, Madura, dan Bali [6].

Di sisi lain masih perlu banyak pengembangan lebih lanjut guna meningkatkan nilai efisiensi DSSC ini. Dalam penelitian awal Penulis pada paper [7] tentang kinerja dari sel surya (DSSC) terhadap pengaruh jumlah antosianin yang terkandung dalam ekstrak kol merah dari tegangan terhadap waktu yang dihasilkan. Dalam penelitian tersebut diketahui bahwa semakin banyak jumlah antosiani, maka semakin tinggi tegangan yang dihasilkan yaitu pada perbandingan pelarut metanol, asam asetat, dan aquades sebesar 40:8:52 [7].

Penulis mengembangkan penelitian pada paper [5] untuk 


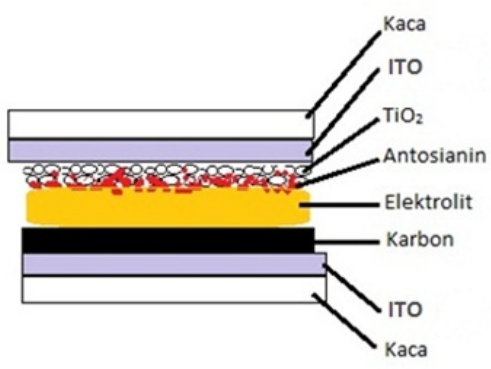

Gambar 1: Skema Dye Sensitized Solar Cell (DSSC) [7]

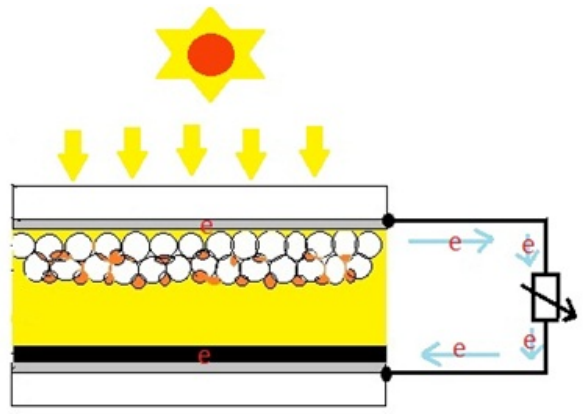

Gambar 2: Sistem kerja DSSC

mengetahui pengaruh pengenceran larutan ekstrak antosianin kol merah dalam kinerja sel surya (DSSC). Dalam penelitian ini ditemukan bahwa pada konsentrasi 100\% (tanpa pengenceran) diperoleh keluaran tegangan terhadap waktu (V-t) yang lebih besar daripada dengan konsentrasi yang lain, begitu juga arus terhadap tegangan (I-V) [5].

Pada artikel ini dilaporkan hasil kajian lanjutan dari hasil penelitian sebelumnya ([5] dan [7]) yakni untuk mengetahui pengaruh $\mathrm{pH}$ larutan antosianin kol merah terhadap efisiensi DSSC. Kajian pustaka tentang derajat keasaman $(\mathrm{pH})$, antosianin, cara kerja DSSC, dan karakterisasi arus-tegangan DSSC pada artikel ini mengacu pada artikel sebelumnya pada halaman 58 di depan, dengan gambar skema dan cara kerja DSSC ditunjukkan Gambar 1 dan 2.

\section{METODOLOGI PENELITIAN}

\section{Bahan dan Alat}

Pada penelian ini bahan-bahan yang digunakan meliputi kaca berlapis ITO (indium-tin oxide), titanium dioxide $\left(\mathrm{TiO}_{2}\right)$, aseton, etanol, metanol, asam asetat, aquades, potassium iodide (KI), iodine $\left(\mathrm{I}_{2}\right)$, polyethylene glycol (PEG).

\section{Ekstraksi Dye Antosianin}

20 gram kol merah yang masih segar ditimbang dengan menggunakan timbangan digital dan ditumbuk dengan mor-

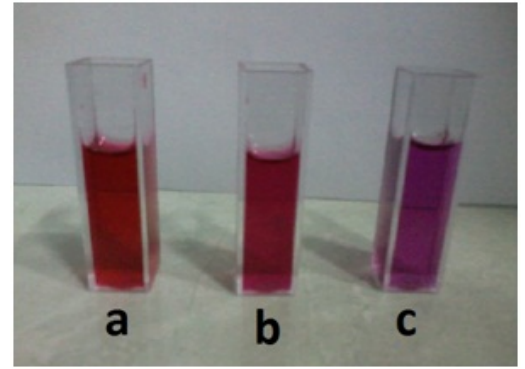

Gambar 3: Larutan ekstrak kol merah a. $\mathrm{pH} 1.5$, b. $\mathrm{pH} 2.5$, dan c. $\mathrm{pH} 3.5$

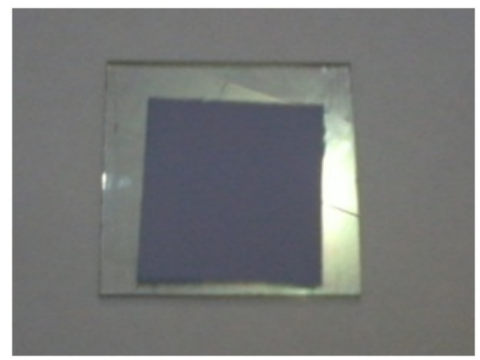

Gambar 4: Skema Pelapisan $\mathrm{TiO}_{2}$ pada Kaca ITO.

tar sampai halus. Selanjutnya kol yang sudah halus dimasukkan dalam tabung erlenmeyer yang sudah dilapisi dengan alumunium foil atau botol yang berwarna gelap dan direndam selama 24 jam dalam campuran pelarut $40 \mathrm{ml}$ metanol, $8 \mathrm{ml}$ asam asetat, dan $52 \mathrm{ml}$ aquades yang sebelumnya sudah diaduk selama 30 menit menggunakan magnetic stirer. Setelah 24 jam ekstrak antosianin kol merah disaring dengan menggunakan kertas saring (filter) dan dimasukkan ke dalam botol gelap atau botol yang telah dilapisi dengan alumunium foil [5]. Setelah hasil ekstrak antosianin diperoleh kemudian di ukur $\mathrm{pH}$ nya dengan menggunakan $\mathrm{pH}$-indicator strips. Untuk membuat larutan ekstrak antosianin dengan $\mathrm{pH}$ yang berbeda-beda dilakukan pengurangan atau penambahan jumlah asam asetat sebanyak $4 \mathrm{ml}$ pada campuran pelarut saat mengekstrak. Hasil ekstrak antosianin kol merah ditunjukan pada Gambar 3.

\section{Preparasi Elektroda $\mathrm{TiO}_{2}$}

Dengan menggunakan multimeter digital kaca berlapis ITO (indium-tin oxide) diukur resistansinya. Kemudian pada bagian tepi kaca berlapis ITO ditutup dengan menggunakan isolatipe seperti pada Gambar 4. sehingga sisa luasan yang dikosongkan mempunyai luasan $15 \mathrm{~mm} \times 15 \mathrm{~mm}$. Selanjutnya dalam pembuatan larutan $\mathrm{TiO}_{2}$ digunakan untuk melapisi kaca ITO. 3,5 gram koloid $\mathrm{TiO}_{2}$ dilarutkan pada $15 \mathrm{ml}$ etanol, lalu diaduk selama 30 menit menggunakan magnetic stirer [14]. Setelah terbentuk pasta $\mathrm{TiO}_{2}$ selanjutnya dilakukan pelapisan pada bagian kaca berlapis ITO yang sudah dibersihkan dengan aseton. Setelah lapisan kering, isolatipe dibuka dan kemudian kaca ITO dipanaskan dengan suhu $200^{\circ} \mathrm{C}$ selama \pm 20 menit. 


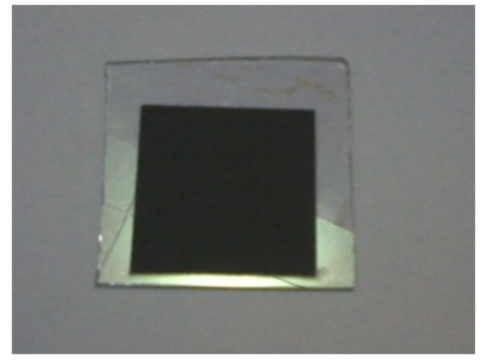

Gambar 5: Skema Pelapisan Karbon pada Kaca ITO.

\section{Preparasi Elektrolit}

Sebanyak 8,30 gram Potassium Iodide (KI) dan 1,26 gr Iodine $\left(\mathrm{I}_{2}\right)$ digunakan untuk membuat elektrolit yang kemudian dilarutkan dalam $100 \mathrm{ml}$ Polyethylene Glycol (PEG). Kemudian larutan elektrolit tersebut diaduk dengan menggunakan magnetic stirrer selama 30 menit. Larutan elektrolit yang sudah jadi kemudian disimpan dalam botol berwarna gelap atau botol yang telah dilapisi dengan alumunium foil [14].

\section{Preparasi Elektroda Karbon}

Kaca berlapis ITO dibersihkan dengan aseton terlebih dahulu kemudian diukur resistansiya dengan menggunakan multimeter digital. Kemudian pada bagian tepi kaca berlapis ITO ditutup dengan menggunakan isolatipe seperti pada Gambar 5. Selanjutnya kaca berlapis ITO dilapisi dengan larutan karbon yang dibuat dari karbon pensil 2B yang sudah dihaluskan dengan mortar, lalu ditimbang sebanyak 3,5 gram yang dilarutkan dalam $15 \mathrm{ml}$ etanol. Kemudian diaduk selama 30 menit menggunakan magnetic stirer hingga terbentuk larutan karbon [15].

\section{Pembuatan dan Karakterisasi DSSC}

Elektroda $\mathrm{TiO}_{2}$ yang telah jadi kemudian direndam dalam larutan ekstrak antosianin yang berbeda $\mathrm{pH}$-nya yaitu masingmasing pada $\mathrm{pH} 1,5 ; 2,5$; dan 3,5 selama 24 jam. Setelah masing-masing elektroda $\mathrm{TiO}_{2}$ direndam dalam larutan ekstrak antosianin, kemudian diangkat dan dikeringkan dengan kertas tisu. Selanjutnya elektroda $\mathrm{TiO}_{2}$, elektrolit, dan elektroda karbon dirangkai seperti struktur wafer yang dicepit dengan binder clips seperti pada Gambar 6 .

Untuk menganalisis karakteristik hasil keluaran dari sel surya yang telah dirangkai selanjutnya diukur arus dan tegangannya (I-V) dengan menggunakan multimeter digital. Pengukuran dilakukan dengan menggunakan sumber cahaya lampu xenon pada jarak $30 \mathrm{~cm}$ seperti pada rangkaian pengukuran (Gambar 7). Nilai arus maupun tegangan keluaran pada sel surya diukur pada setiap variasi hambatan mulai dari hambatan maksimal hingga minimalnya. Selanjutnya hasil pengukuran yang didapat dibuat kurva I-V kemudian dianalisis untuk mengetahui performa dari sel surya.

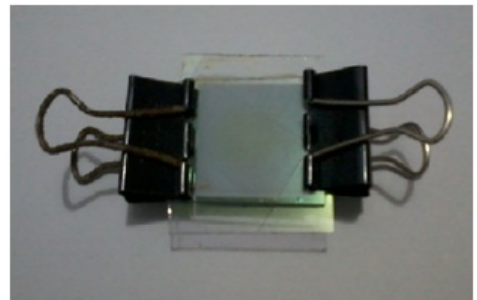

Gambar 6: Struktur wafer sel surya DSSC

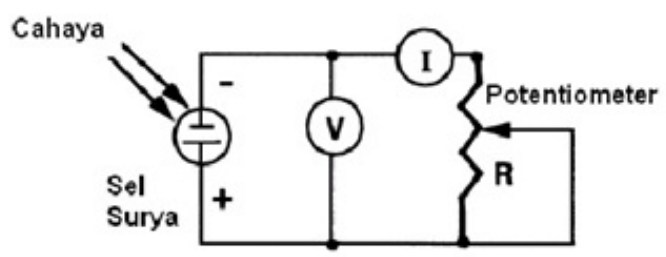

Gambar 7: Rangkaian pengukuran DSSC [4] dengan modifikasi gambar.

\section{HASIL DAN PEMBAHASAN}

\section{Karakterisasi Arus dan Tegangan}

Berdasarkan pengukuran $\mathrm{pH}$ larutan ekstrak antosianin kol merah dengan menggunakan $\mathrm{pH}$-Indikator strips didapatkan $\mathrm{pH} 3,5$ pada larutan dengan pengurangan asam asetat $4 \mathrm{ml}$ (40 $\mathrm{ml}$ methanol : $4 \mathrm{ml}$ asama setat : $52 \mathrm{ml}$ aquades), pada larutan ekstrak tanpa penambahan atau pengurangan asam asetat (40 $\mathrm{ml}$ methanol : $8 \mathrm{ml}$ asam asetat : $52 \mathrm{ml}$ aquades) didapatkan $\mathrm{pH} 2,5$, sedangkan pada penambahan $4 \mathrm{ml}$ asam asetat $(40 \mathrm{ml}$ methanol : $12 \mathrm{ml}$ asam asetat : $52 \mathrm{ml}$ aquades) didapatkan $\mathrm{pH}$ 1,5, seperti ditunjukan pada Gambar 8.

Pada Gambar 9, disajikan kurva pengaruh $\mathrm{pH}$ larutan ekstrak kol merah pada karakteristik arus terhadap tegangan (I-V) dari sel surya dengan penyinaran lampu xenon 1000 watt $/ \mathrm{m} 2$ pada jarak $30 \mathrm{~cm}$. Seperti pada Table I. dapat dilihat bahwa $\mathrm{pH}$ larutan mempengaruhi parameter-parameter hasil kinerja sel surya. Dari data hasil pengujian sel surya tersebut, maka dapat diketahui nilai efisiensi konversi energi $(\eta)$ sel surya dengan menggunakan Pers. (1), (2), dan (3).

Pada sel surya yang direndam dalam larutan ekstrak antosianin kol merah dengan $\mathrm{pH}$ 3,5 ditunjukkan nilai tegangan rangkaian buka $\left(\mathrm{V}_{o c}\right)$ sebesar $250 \mathrm{mV}$ dengan besar arus rangkaian pendek $\left(\mathrm{I}_{o c}\right)$ sebesar $56 \mu \mathrm{A}$. Tegangan maksimum $\left(\mathrm{V}_{\text {max }}\right)$ yang dihasilkan sebesar $153 \mathrm{mV}$, sedangkan arus maksimum $\left(\mathrm{I}_{\max }\right)$ sebesar $38 \mu \mathrm{A}$. Besar rapat arus pada luasan $15 \times 15 \mathrm{~mm}^{2}$ sebesar $24,89 \mu \mathrm{A} / \mathrm{cm}^{2}$. Nilai efisiensi konversi sel surya baru mencapai 2,55 × 10 $0^{-3} \%$ (Gambar 9(a)).

Sedangkan sel surya yang direndam dalam larutan ekstrak antosianin kol merah dengan $\mathrm{pH}$ 2,5 menunjukkan tegangan rangkaian buka $\left(\mathrm{V}_{o c}\right) 39 \mathrm{mV}$ dengan besar arus rangkaian pendek $\left(\mathrm{I}_{s c}\right) 52 \mu \mathrm{A}$. Tegangan maksimum $\left(\mathrm{V}_{\max }\right)$ yang dihasilkan $27 \mathrm{mV}$, sedangkan arus maksimum $\left(\mathrm{I}_{\max }\right) 43 \mu \mathrm{A}$. 


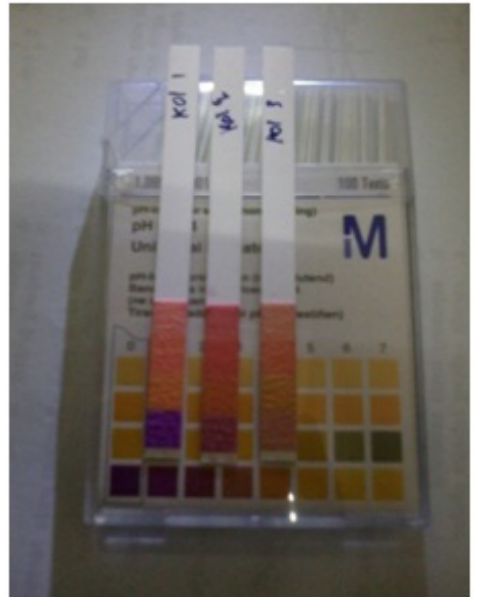

Gambar 8: Pengecekan besar pH dengan $\mathrm{pH}$-indicator strips, kol 1 menunjukan $\mathrm{pH}$ 1,5 merupakan larutan dengan penambahan asam asetat $4 \mathrm{ml}$, kol 2 menunjukan $\mathrm{pH}$ 2,5 merupakan larutan tanpa penambahan atau pengurangan asam asetat, dan kol 3 menunjukan $\mathrm{pH}$ 3,5 merupakan larutan dengan pengurangan asam asetat $4 \mathrm{ml}$.

TABEL I: Parameter-parameter Sel Surya DSSC

\begin{tabular}{|c|c|c|c|c|c|c|c|}
\hline $\begin{array}{c}\mathrm{pH} \text { Larutan } \\
\text { Ekstrak } \\
\text { Antosianin }\end{array}$ & $\begin{array}{c}\mathrm{I}_{s c} \\
(\mu \mathrm{A})\end{array}$ & $\begin{array}{l}\mathrm{V}_{o c} \\
(\mathrm{mV})\end{array}$ & $\begin{array}{l}\mathrm{I}_{\max } \\
(\mu \mathrm{A})\end{array}$ & $\begin{array}{l}\mathrm{V}_{\max } \\
(\mathrm{mV})\end{array}$ & $\begin{array}{c}\text { Jsc } \\
\left(\mu \mathrm{A} / \mathrm{cm}^{2}\right)\end{array}$ & FF & $\begin{array}{c}\eta \\
\left(10^{-3} \%\right)\end{array}$ \\
\hline Kol merah & & & & & & & \\
\hline 3,5 & 56 & 250 & 38 & 153 & 24,89 & 0,41 & 2,55 \\
\hline 2,5 & 52 & 39 & 43 & 27 & 23,11 & 0,57 & 0,51 \\
\hline 1,5 & 44 & 6,6 & 4,6 & 31 & 19,56 & 0,49 & 0,06 \\
\hline
\end{tabular}

Besar rapat arus sebesar $23,11 \mu \mathrm{A} / \mathrm{cm}^{2}$. Nilai efisiensi konversi sel surya mencapai $0,51 \times 10^{-3} \%$ (Gambar 9(b)).

Pada perendaman sel surya dalam larutan ekstrak antosianin kol merah dengan $\mathrm{pH}$ 1,5 ditunjukkan nilai tegangan rangkaian buka $\left(\mathrm{V}_{o c}\right) 6,6 \mathrm{mV}$ dengan besar arus rangkaian pendek $\left(\mathrm{I}_{s c}\right) 44 \mu \mathrm{A}$. Tegangan maksimum $\left(\mathrm{V}_{\max }\right)$ yang dihasilkan $31 \mathrm{mV}$, sedangkan arus maksimum $\left(\mathrm{I}_{\max }\right)$ 4,6 $\mu \mathrm{A}$. Besar rapat arus $19,56 \mu \mathrm{A} / \mathrm{cm}^{2}$, nilai efisiensi konversi sel surya mencapai $0,06 \times 10^{-3} \%$ (Gambar 9(c)).

Dari Tabel I, dapat dilihat bahwa keluaran yang dihasilkan DSSC untuk $\mathrm{TiO}_{2}$ yang direndam dalam cairan ekstrak antosianin pada $\mathrm{pH} 3,5$ selama 24 jam menghasilkan efisiensi konversi keluaran paling besar yaitu 2,55 × $10^{-3} \%$ (Gambar 11(a)), hasil ini sedikit lebih baik dibandingkan dengan hasil yang didapat pada penelitian Anita, $d k k$. [15] dengan menggunakan klorofil daun kacang panjang sebagai dye dengan efisiensi konversi $2 \times 10^{-3} \%$, tetapi efisiensi ini masih kecil dibandingkan dengan Michael Grätzel et al. [3] dengan menggunakan dye sintetis yang mencapai $11 \%$, seperti terlihat pada Gambar 10.

Sedangkan pada $\mathrm{pH}$ 1,5 menunjukan efisiensi konversi keluaran paling kecil. Ini memperlihatkan pada larutan $\mathrm{pH} 3,5$ memiliki kinerja sel surya yang paling efektif. Hal ini dikarenakan $\mathrm{pH}$ larutan merupakan salah satu faktor yang mempengaruhi stabilitas dari antosiani, sehingga mempengaruhi nilai efisiensi yang dihasilkan. Hasil ini berlawanan dengan

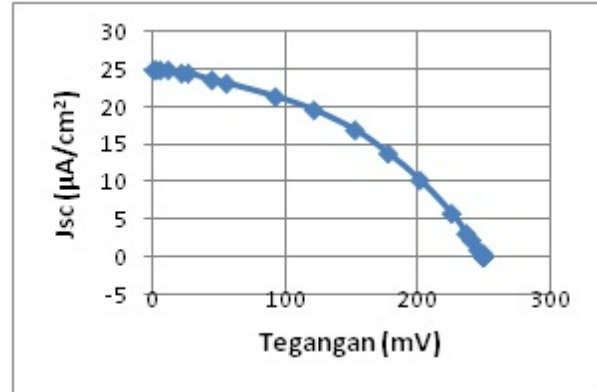

(a) $\mathrm{pH} 3,0$

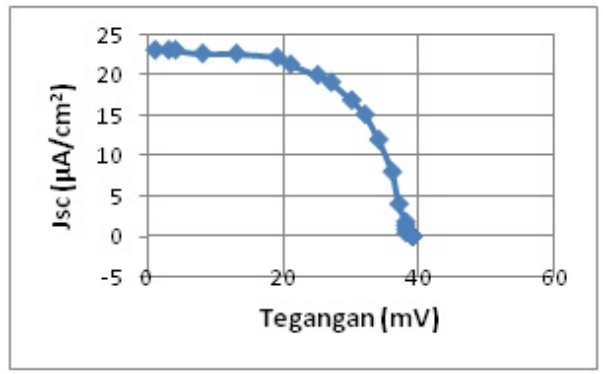

(b) $\mathrm{pH} 2,5$

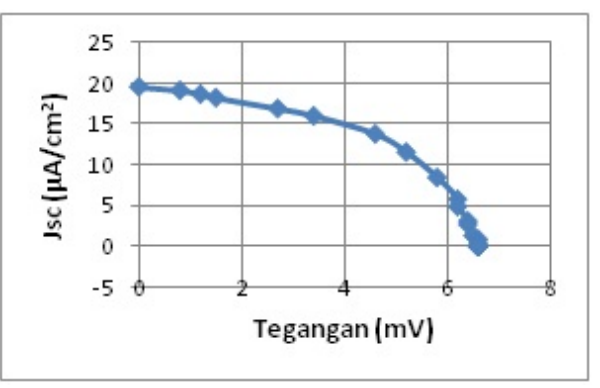

(c) $\mathrm{pH} 2,0$

Gambar 9: Grafik karakteristik arus-tegangan DSSC dengan perbedaan $\mathrm{pH}$ pada perendaman $24 \mathrm{jam}$. (a) $\mathrm{pH}$ 3,5 (40 ml methanol : 4 $\mathrm{ml}$ asama setat : $52 \mathrm{ml}$ aquades), (b) $\mathrm{pH} 2,5$ (40 ml methanol : $8 \mathrm{ml}$ asama setat : $52 \mathrm{ml}$ aquades), dan (c) $\mathrm{pH} \mathrm{1,5} \mathrm{(40} \mathrm{ml} \mathrm{methanol} \mathrm{:} 12$ $\mathrm{ml}$ asama setat : $52 \mathrm{ml}$ aquades).

penelitian lain yang menggunakan ekstrak antosianin strawberry dimana pada $\mathrm{pH} 2$ justru menunjukan kinerja yang paling efektif. Ini disebabkan susunan struktur kimia dasar dari antosianin kol merah dan strawberry yang berbeda sehingga mengakibatkan berbedanya hasil keluaran. Hasil keluaran ini lumayan cukup besar terutama pada arus keluaran pada sel surya dibandingkan dengan penelitian A. Maddu, dkk. [4] dan Anita, dkk. [15] yang dikarenakan pada lapisan gabungan elektroda $\mathrm{TiO}_{2}$ - elektrolit - elektroda karbon nilai resistansinya sudah relative lebih kecil yaitu 1,4 kiloOhm $(\mathrm{k} \Omega)$ dibanding dengan penelitian sebelumnya mencapai orde megaOhm $(\mathrm{M} \Omega)[4,15]$. Nilai resistansi yang cukup kecil ini mengakibatkan elektron yang diinjeksi dari dye mengalami hambatan yang lebih kecil di dalam lapisan $\mathrm{TiO}_{2}$ sehingga jumlah elektron yang mengalir ke rangkaian luar menjadi lebih besar, akibatnya arus yang dihasilkan juga lebih besar. Sel surya ini juga belum dapat sempurna yang dimungkinkan 


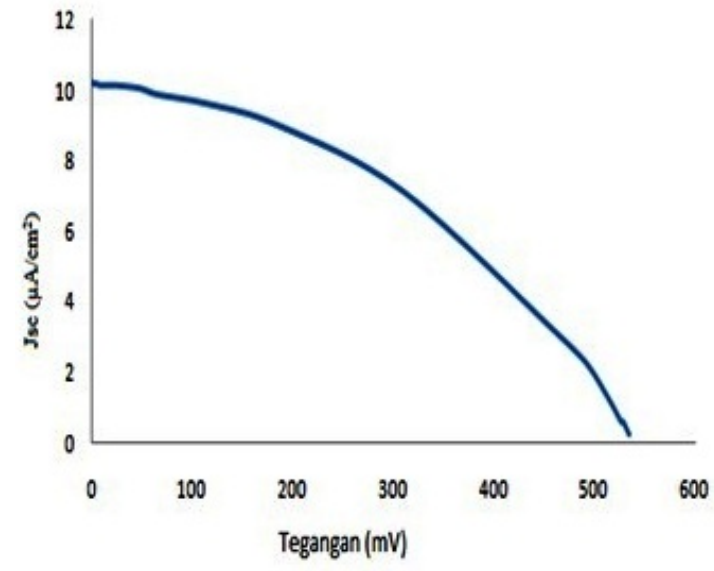

(a) $\mathrm{pH} 3,0$

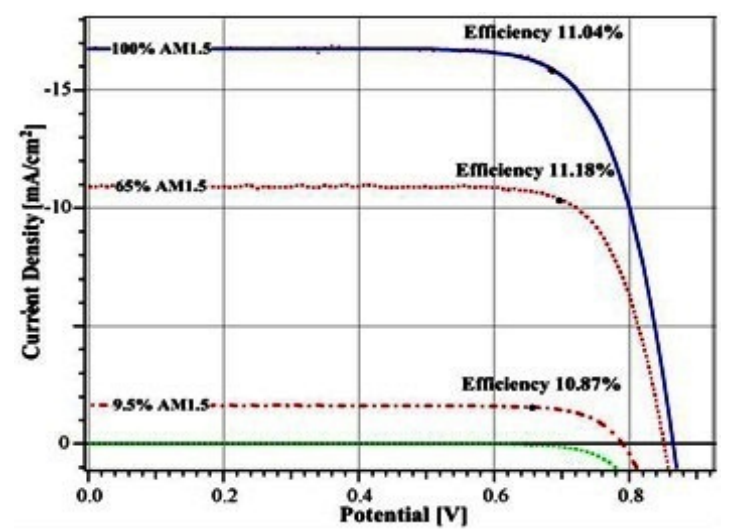

(b) $\mathrm{pH} 2,5$

Gambar 10: Grafik karakteristik arus-tegangan DSSC (a) pada penelitian Anita[15] dan (b) pada penelitian Michael Grätzel[3].

belum optimalnya penyerapan dye dan fungsi dye itu sendiri dalam proses injeksi elektron pada elektroda $\mathrm{TiO}_{2}$.

\section{SIMPULAN}

Penelitian ini berisi tentang laporan penelitian tentang pengaruh $\mathrm{pH}$ larutan ekstrak antosianin kol merah terhadap kinerja sel surya (DSSC). Sel surya yang digunakan dalam penelitian telah direndam selama 24 jam pada larutan $\mathrm{pH} 3,5$;
2,5; dan 1,5. Ditemukan bahwa pada perendaman larutan $\mathrm{pH} 3,5$ diperoleh keluaran tegangan rangkaian buka $\left(\mathrm{V}_{o c}\right)$ dan arus rangkaian pendek ( $\mathrm{I}_{s c}$ yang lebih besar daripada dengan $\mathrm{pH}$ lainnya yaitu $250 \mathrm{mV}$ dan $56 \mu \mathrm{A}$. Tegangan maksimum $\left(\mathrm{V}_{\max }\right)$ dan arus maksimum $\left(\mathrm{I}_{\max }\right)$ masing-masing sebesar $153 \mathrm{mV}$ dan $38 \mu \mathrm{A}$. Besar rapat arus pada luasan $15 \times 15$ $\mathrm{mm}^{2}$ sebesar $24,89 \mu \mathrm{A} / \mathrm{cm}^{2}$, sedangkan nilai efisiensi konversi sel surya mencapai $2,55 \times 10^{-3} \%$. Dari hasil penelitian didapatkan kinerja sel surya yang paling efektif yaitu pada perendaman larutan ekstrak antosianin kol merah dengan $\mathrm{pH}$ 3,5 .
[1] D.A. Widodo, dkk., Pemberdayaan Energi Matahari Sebagai Energi Listrik Lampu Pengatur Lalu Lintas, Artikel Penelitian, Universitas Negeri Semarang, Semarang, 2009.

[2] M. Grätzel, J. Photochemistry and Photobiology C: Photochemistry Reviews 4, 145-153 (2003).

[3] M. Grätzel, Chimie 9, 578-583 (2005).

[4] A. Maddu, M. Zuhri, dan Irmansyah, Makara, Teknologi 11(2), 78-84 (2007).

[5] F.R. Saputra, F.S. Rondonuwu, A. Sutresno, Pemanfaatkan Ekstrak Antosianin Kol Merah (Brassica Oleracea Var) Sebagai Dye Sensitized dalam Pembuatan Prototipe Solar Cell (DSSC), Seminar Nasional Sains dan Pendidikan Sains VIII 4(1), 332$333,2013$.

[6] Listrik dan Sumber Energi Baru [http://www.suaramerdeka.com/ v1/index.php/read/cetak/2012/06/22/190272/10/Listrik-danSumber -Energi-Baru]. (22 juni 2012)

[7] F.R. Saputra, F.S. Rondonuwu, A. Sutresno, Identifikasi Antosianin Kol Merah (Brassica oleracea var) untuk Potensi sebagai Dye Sensitized Solar Cell (DSSC), Seminar Nasional $2^{\text {nd }}$ Lontar Physics Forum 2013 LPF 1345.

[8] Seafast Center, Merah-Ungu Antosianin, Pewarna Alami untuk Pangan (23-43) 2012.
[9] P.K. Das, et al., Plant Signaling and Behavior 6(1) (2011).

[10] V. Ekasari, dan G. Yudoyono, Jurnal Sain dan Seni POMITS 2(1), 2337-3520 (2013).

[11] J.M.R.C. Fernando, and G.K.R. Senadeera, Current Science 95(5), 663-666 (2008).

[12] M.S.W. Kumara, dan G. Prajitno, Studi Awal Fabrikasi Dye Sensitized Solar Cell (DSSC) dengan Menggunakan Ekstraksi Daun Bayam (Amaranthus Hybridus L.) sebagai Dye Sensitizer dengan Variasi Jarak Sumber Cahaya pada DSSC, Laporan Penelitian, Institut Teknologi Sepuluh Nopember, Surabaya 2012.

[13] T. Marinado,T., Photoelectrochemical studies of dye sensitized solar cells using organic dyes (Kungliga Tekniska Högskolan, Stockholm, 2009).

[14] W. Septina, dkk., Pembuatan Prototipe Solar Cell Murah dengan Bahan Organik-Inorganik (Dye-sensitized Solar Cell), Laporan Penelitian Bidang Energi, Instiut Teknologi Bandung, Bandung 2007.

[15] Anita, dkk., Karakteristik Klorofil Pada Daun Kacang Panjang (Vigna Sinensis) sebagai Dye-Sensitized Solar Cells, Seminar Nasional $2^{\text {nd }}$ Lontar Physics Forum 2013 LPF 1353. 